\title{
Ethnography of the socio-sanitary reception in Rome. How are HIV/AIDS and hepatitis $b$ involved in creating the construction of legal categories assigned to migrants?
}

\section{Cecilia Santilli}

\section{Cecilia Santilli is based at the Faculty of Social Sciences, School of Social Work, Lund University, Lund, Sweden. \\ Received 2 July 2019 Revised 29 October 2020 Accepted 21 January 2021 \\ () Cecilia Santilli. Published by Emerald Publishing Limited. This article is published under the Creative Commons Attribution (CC BY 4.0) licence. Anyone may reproduce, distribute, translate and create derivative works of this article (for both commercial and non-commercial purposes), subject to full attribution to the original publication and authors. The full terms of this licence may be seen at http:// creativecommons.org/licences/ by/4.0/legalcode}

This article is based upon doctoral research supported by Sidaction, the Université Franco-Italienne and the Ecole Française de Rome and has been approved by the Inserm (French Institute of Health and Medical Research) Ethics Committee and the CNIL and interviews were conducted respecting the anonymous, status. Thanks are due to the staff, volunteers and migrants whom I have met and interviewed at the association where fieldwork was carried out. I have no conflicts of interest to disclose.

\begin{abstract}
Purpose - This paper aims to investigate the role that Italian third sector organizations have in the process of social and administrative categorization of newly arrived migrants living with human immunodeficiency virus/acquired immunodeficiency syndrome (HIV/Aids) or hepatitis b. In Italy, free access to health is provided to all migrants and residence permits for medical treatment is granted for migrants living with a "serious illness" since the 1990s. The case of HIV/Aids and hepatitis b shows how this political openness, however, clashes with the tightening of migration policies.
\end{abstract}

Design/methodology/approach - The study is based on ethnographic research conducted between 2014 and 2016 within an associative centre that deals with the socio-health care of newly arrived migrants in Rome. In addition to the participant observations, the study is based in semi-structured interviews conducted with 10 health-care providers (nurses, health-care assistants and socio-cultural mediators) and doctors and with 22 migrants coming from Sub-Saharan Africa and living with HIVIAIDS (10) and hepatitis b(12)

Findings - In Italy, the two infections have been identified as top diseases among migrant populations in the country but if HIV/Aids is always considered as a "serious illness", hepatitis $b$ is considered as a public health priority only in the case of a treatment prescription. These aspects have an important impact on the interactions between medical and social professionals and migrants affected by HIVIAIDS and hepatitis $b$, contributing differently to the creation of legal categories assigned to migrants.

Originality/value - The case of HIV/Aids and hepatitis b shows how the political openness of the public health system, clashes with the tightening of migration policies and analyse the role of the third sector has in this issue.

Keywords HIV, Italy, Civil society, Third sector, Migrants, Access to health care, Hepatitis b

Paper type Research paper

\section{Introduction}

Since the 1990s, the tightening of migration policies in Europe is increasingly based on the difference between "legal" and "illegal" migrant or in the case of asylum seekers, between "true" refugees and "false" refugees (De Genova, 2002; d'Halluin, 2012). These public notions are used to select deserving migrants and are part of a political context where the suspicion towards migrants and the perception of "limited resources" dominate. These "policies of suspicion" (d'Halluin, 2012), characterized by the search for signs proving the unfounded nature of asylum or humanitarian applications, have taken increasingly 
restrictive forms since the economic crisis of 2008 because of the recent intensification of migratory flows towards the European continent and the economic rationalization of the welfare states (Santilli, 2017). Many studies have stressed that, in the current migratory context, a diseased or suffering migrant has more possibilities to have access to social rights and to a residence permit than another migrant, especially if the disease is considered as a public health priority (Fassin, 2001; Ticktin, 2011; Willen, 2012, 2015).

The question of local moral values and local political dynamics, through which the right to access health care and residence permit is granted to certain social groups and patients living with one specific disease rather than to others, still needs to be investigated (Rosenthal, 2007; Willen, 2012). The policies of suspicion take various forms in accordance to the local and national contexts. Moreover, as ethnographic studies have shown, they have not only extended to competent public institutions, which decide on the issue of a residence permit but also in a non-profit context (Castaneda, 2009; d'Halluin, 2012; Sorgoni, 2011; Vacchiano, 2011). According to Lipsky and Smith (1993, p. 3), non-profit actors "play a new political role in representing the welfare state to its citizens, providing a buffer between state policy and service delivery" and for that reason, they may be even more legitimate to select migrants than public institutions.

Other scholars have nuanced these results showing that civil society actors, by providing alternative services, promoting networks and acting in the political arena, play also the role of challengers and are a vehicle for political socialization (Ambrosini, 2015; Zamponi, 2018).

This article seeks to add to the debate on the role played by civil society actors in migration control policies by looking at the everyday practices at the local level. As highlighted by Maurizio Ambrosini and Joanne Van Der Leun, "civil society's role with respect to service provision has not yet been adequately explored at the local level" (2015, p. 104).

With these insights in mind, the article investigates the role that Italian third sector organizations may have in the process of social and administrative categorization of newly arrived migrants living with human immunodeficiency virus/acquired immunodeficiency syndrome (HIV/Aids) or hepatitis $b$ through an analysis of the daily practices of health and social professionals working within an associative centre that deals with the socio-health care of newly arrived migrants (irregular migrants, asylum seekers, etc.) in Rome called Samifo.

The Italian case is of particular interest for understanding the role that third sector actors play today in resolving the contradictions that arise when health policies meet with migration policies because of their leading role played in the provision of services for new arrived migrants. In Italy, free access to health is provided to all migrants and residence permits for medical treatment (called humanitarian permit) is granted for migrants living with a "serious illness" since the 1990s. However, there is an increasing gap between the official policies and the real provision of non-urgent medical care entrusted to the associative world (Ambrosini, 2015).

HIV/Aids and hepatitis b has been identified as top diseases among migrant populations in the country but if the first one is always considered as a "serious illness", the second one is considered as a public health priority only in the case of a treatment prescription. This aspect shows how political openness relies on health systems based on the principle of universalism clashes with the tightening of migration policies and the economic rationalization of the health system. Moreover, the taking charge of newly arrived migrants living with the two infections is increasingly entrusted to third sector organizations (Santilli, 2017; Borzaga and Fazzi, 2011; Giarelli et al., 2014). The so-called "terzo settore" is an associative system mainly funded by the State with the objective to support the welfare state, increasingly challenged by the economic rationalization (Borzaga and Fazzi, 2014) and by the increasing number of requests from migrants. With limited economic and human resources, the associations dealing with migrants are forced not only to select migrants entitled to receive help but also to implement differentiated treatments of migrants according to their social status and pathology. 
The aim of this article is to point out how the professionals of Samifo internalize and use the categories of asylum seeker, refugee, diseased migrant, HIV/Aids and hepatitis b in the social treatment of migrant seeking for refugee status or humanitarian permit. Moving from the legislative level to that of its implementation (Castañeda, 2009; Willen, 2012) in the Italian context, this study contributes to the analysis of the way in which migration policies are conducted, favouring certain migrants who "deserve" to be accepted rather than others, through a set of practices and actors that integrate and implement what the current legislation prescribes (Musso, 2012; Musso et al., 2012).

After a presentation of the method used to carry out my analysis, I will present the Italian migration and health policies, then I focus on the Italian policies adopted to fight against HIV/AIDS and hepatitis B among the migrant populations. Finally, I attempt to demonstrate the impact of these policies on the interactions between medical and social professionals and migrants affected by HIV/AIDS and hepatitis $b$ and how these two infections contribute to the creation of legal categories assigned to migrants. In the article, I will use the terms "HIV" and "HIV/AIDS", as well as the terms "hepatitis b" and "hepatitis b virus (HBV)". It is important to note that in a biomedical point of view there are important differences between all these notions. HIV stands for human immunodeficiency virus and is the virus that can lead to acquired immunodeficiency syndrome or AIDS, if not treated. Hepatitis b is a liver infection caused by the HBV, which can cause acute or chronic illness.

\section{Methodology}

The present article is based on an ethnographic research conducted between 2014 and 2016 within an association dealing with medical, psychological and social issues of newly arrived migrants applying for a residence permit (refugee status or humanitarian permit), in Rome (Samifo, Centro di Salute per Migranti Forzati - Health Centre for Forced Migrants). The Samifo has been chosen for this study because it is the most active associative centre in providing medical care to the newly arrived migrants asking for asylum in the region Lazio and because it offers infectiology service to these migrants (Santilli, 2017). The association has been recognized by the state in 2015 as an actor providing public utility services and was established in 2006 from a collaboration between the Jesuit Refugee Service association and the Azienda Sanitaria Locale (local unit of public health facilities) of Rome. The Samifo is composed of employees of the public hospital, members of the Jesuit Refugee Service association and volunteers. The services it offers are, namely, general medicine, psychiatry, psychology, gynaecology, infectiology, social assistance, interpreting. To understand the interactions between social and health professionals and migrants, I accompanied patients with HIV/Aids or hepatitis b during their consultations with the various doctors (general practitioner, psychologist, psychiatrist and infectiologist) and during their meetings with the social workers assisting them in their administrative procedures. In the association, I took on the role of volunteer helping the staff members in their daily work (Santilli, 2017). I was a linguistic mediator from French to Italian and vice versa helping professionals and migrants in their interactions. This methodological choice is due to the difficulty in accessing data in the context of structural violence (d'Halluin, 2005; Vidal, 1996). Migrants accepted in these associations are involved in difficult situations due to political, economic and psychological problems, so it is necessary to build up a relationship of trust before proceeding with research and interviews. Furthermore, this choice enables to create trust also with the members of the associations and to reduce the conflicts caused by the research itself (Vidal, 1996). As shown by Estelle d'Halluin who used a similar ethnografic approach for her research in a French asylum centre (2005); being engaged as a volunteer who helps migrants in their interactions with other professionals and in their administrative procedures does not imply that they accept to participate in the research. In fact, not all the migrants met during the fieldwork are considered in this study (Santilli, 2017). 
In addition to the participant observations, the article is based in semi-structured interviews conducted with 10 health-care providers (nurses, health-care assistants and socio-cultural mediators) and doctors and with 22 migrants coming from Sub-Saharan Africa and living with HIV/AIDS (10) and hepatitis b (12), 28-35years of age. Among these, there were 12 men and 10 women. Migrants have been selected with the help of the doctors. The patients for which the participation to the study was considered too stressful by the doctors have been excluded. The ethnography approach implies two ethical issues, namely, the ethical issue of the fieldwork and the ethical issue of the analysis (Sakoyan, 2008). Concerning the fieldwork, I informed all people interviewed of my research. Migrants have been informed at first by their doctor and in a second time by myself. During our first meeting, I asked them if I could have interviewed them and participated to their consultations and meeting with all professionals. The patients interviewed signed a consent form. The research has been approved by the Inserm (French Institute of Health and Medical Research) Ethics Committee and the CNIL (National Commission on Informatics and Liberty). Regarding the analysis, I conducted and analized all the interviews respecting the anonymous status. Moreover, as usually done in ethnographical works (Alder and Alder, 2000), I sometimes omitted personal information that might have compromised patients or professionals (Santilli, 2017).

The sample of surveyed migrants reflects the proportion of the migrant population suffering from these two infections and visiting the Samifo (2014). Nevertheless, the results presented here do not reflect the entire Italian reception system, and therefore, cannot be generalized to all migrants living with HIV/AIDS and hepatitis $b$.

The data was coded and analysed both deductively and inductively, grouping codes into larger categories and then generating theoretical categories (Strauss and Corbin, 1994).

\section{Findings}

\subsection{Political context}

Historically, Italy has been considered as a country of emigration and transit rather than of immigration. This has had the political consequence of maintaining a certain level of nonregulation with regard to immigration policies. From the 1970s, Italy became a country of immigration and reception (Pugliese, 2002). Immigration policy has changed little since then, despite the laws that, from the end of the 1980s, have tightened border control (Zincone, 2011). The Italian migration policy has always been characterized by an "amalgamation between immigration and asylum" (Morroi, 2012: 76) and both public debates and migration policy have since the 1980s been constantly dominated by the terms of "emergency" and "exceptionality" (Santilli, 2017; Dal Lago, 2004; Ravenda, 2011; Zincone, 2011). In this regards, many scholars have highlighted the re-active character of Italian politics as opposed to the pro-active (preventive) character practiced by other countries (Dal Lago, 2004; Delle Donne, 1995; Zincone, 2011) and shown that the majority of migration laws and reforms has been a response to emergency events (Zincone, 2011).

When it comes to the health of migrants, Italy differs from the majority of European countries in the implementation of some legal measures guaranteeing access to care for all migrants, also for "undocumented migrants" (Ambrosini, 2015) and a residence permit for those suffering from a specific and serious illness. The first law, called "Turco-Napolitano" or "Testo Unico" Act of 1998 (Decreto legislative 286/1998), guarantees free access to the national health system - not just for emergency treatment - to all migrants, including irregular migrants. This Act states that all migrants living in a precarious economic situation can benefit from urgent treatment, complete medical care and even tests, all free of charge. Care and monitoring of pregnancy, care of children, vaccines, prevention, management and detection of infectious diseases are also free of charge. The second law (Decreto legislativo 25/08), adopted in 2008, stipulates the impossibility to expel a migrant in serious 
health condition from Italy. Migrants suffering from a specific illness can obtain the so-called "humanitarian" permit granted by the police bureau or by the Territorial Commission, which examines asylum applications.

This political openness, however, clashes with the tightening of migration policies and the economic rationalization of the social and health systems. In fact, in recent years, the increasing number of migrants arriving in Italy and the economic crisis started in 2008, have brought the government to call into question the public spending on the migrant's reception system and on their health. The fact that the migration crisis has grown out of a context of economic crisis and of welfare retrenchment has resulted in growing anti-migrant sentiments in the country (Caponio and Cappiali, 2018). The more restrictive migration policies based rather as in past on extraordinary interventions than on a structural reformation of the Italian reception system, have not changed the general public's perception of a wave of migrants invading the country (Caponio and Cappiali, 2018; Santilli, 2017). In this context, the public debate surrounding asylum seekers and migrants is dominated by the distinction between the notions of "true refugee" - a victim of political persecution - and "bogus asylum seekers" - migrant who is not really a humanitarian victim, but is moving for economic reasons. As in other European countries, this rhetoric has become a way of "morally delineating the deserving refugee from the undeserving migrant" (Holmes and Castañeda, 2016: 13) and reflects the public rise of suspicious sentiments towards migrants.

\subsection{The role of associative actors}

Another consequence of the tougher measures for the treatment of migrants is the increasing gap between the official policies and the real provision of non-urgent medical care that is increasingly entrusted to the associative world (Ambrosini, 2015). In general, the inconsistencies of Italian migration policy have been counterbalanced by the action of third sector actors (associations, non-profit organizations and cooperatives) and organized at the local level. The reception and assistance to migrants have been transferred to civil society actors, which have always been crucial for migrant settlement and integration (Ambrosini, 2015; Zincone, 1999). However, civil society actors are also going through the economic rationalization begun in the 2000s and increased with the austerity policies following the economic crisis (Bosi and Zamponi, 2015). The associations dealing with migrants' social and health issues are therefore, in a paradoxical and contradictory situation: on the one hand, they must guarantee universalism and egalitarianism of health systems in economic difficulty, on the other, they are in the condition of not having the economic and human resources to do it fully.

Since 2014, Italy is among the five European Union countries with the highest number of migrants; a significant proportion from sub-Saharan Africa, a region of the world heavily affected by HIV/AIDS and hepatitis b (WHO, 2015). Therefore, some of them are affected by these two infections (Zuccaro, 2012; Istituto superiore di sanità, 2012). Having HIV and HBV the some transmission routes (blood, sexual or mother-to-child), these viruses give rise to similar representations and questions in migrant patients (Pourette, 2013). However, the biomedical characteristics of these two infections are very different, especially in terms of duration of treatment and risk of transmission (HBV is 100 times more contagious than HIV, although there is a vaccine that can limit this contagion). In addition, the circumstances of transmission among migrants from sub-Saharan Africa are not the same: a significant proportion of migrants living with HIV had been infected after their arrival in Europe while the majority of migrants living with hepatitis b seems to have been infected during childhood (Desgrées du Loû et al., 2015; Rice, Elford et al., 2012). It is important to note that at the biomedical level it is quite difficult to establish when the virus has been transmitted. What is known is that in high-prevalence areas, such as sub-Saharan Africa, it is likely that people become infected in the first few years of life. 
In addition, the health political strategies to fight against hepatitis $b$ and HIVIAIDS among migrant populations are different and that may lead to differences in patients' therapeutic and social trajectories.

In Italy, the issue of the health of migrants appeared in the public debates during the 1990s and was linked to the issue of the AIDS epidemic. A committee composed by infectious disease experts was even set up by the Minister of Health, Francesco De Lorenzo, to discuss the link existing between the migrant population and AIDS. Some associations working in the field of migrants' health (such as Caritas in Rome or Naga in Milan) mobilized to prevent AIDS from being automatically associated with migrants coming from subSaharan Africa and to demand the adoption of a law, which would guarantee them the right to care:

"When we started the work for preparing the Turco Napolitano act, we had few cases of AIDS patients in Italy, so this pathology did not influence the work of the associations. Actually, it must be said that almost all political parties approved that law and it was during the "AIDS period". We could assume that the fear of a risk to public health played a role in the adoption of this law: it was the period "AIDS = African immigrant". This aspect has diminished over time, fortunately the law on migrant health covers all diseases: at the end Italy has not made a specific policy for migrants with AIDS. Thanks to this law, we have seen the number of infected migrants decrease" (Massimo, Chief Medical Officer, Caritas).

In the 2000s, the Ministry of Health released a circular with specific provisions for fighting HIV/ AIDS, presented as a "serious illness", which should allow foreigners suffering from this disease to obtain a residence permit. In addition, recommendations on the care of migrants with HIV have also been published by the Ministry of Health (Circular No. 5 of 24 March 2000).

Concerning Hepatitis b, there were less mobilizations. The Ministry of Health released a National plan for fighting hepatitis $b$ and $c$ only in 2015 (Piano nazionale per la prevenzione delle epatiti virali da virus B e C - National Plan for the prevention of viral hepatitis B and C.), and at the Conference "health and migration: new international and national scenarios", held that same year, hepatitis b was identified as one of the top emerging diseases among the migrant population in Italy. However, no measure aimed at fighting this disease among migrant populations has been undertaken so far, and epidemiologic data are still pending. The scientific committee dealing with the National programme for health protection and social and medical assistance for migrant populations in the following years has not included hepatitis in the national priority action plan for the years 2015-2019, despite the data showing hepatitis b prevalence among migrant populations at global (WHO, 2015) and national level (Seiva, 2015). The lack of mobilization explains why there have been no specific legal measures for migrants with hepatitis $b$; only those with chronic hepatitis $b$ who had a treatment prescription could hope for a residence permit for "serious illness".

\subsection{The violence of categorizations: when the logic of compassion interferes with the logic of control}

In giving socio-legal support to newly arrived migrants living with HIV/AIDS or hepatitis b, professionals working in centres like Samifo find themselves at the crossroads of contradictory injunctions. They are caught between the logic of migration policy and the logic of health policy, that is to say between the logic of selection of those who have the right to be accepted, living out those who have not that right and the logic of universalism. In this context, HIV/AIDS and hepatitis b play a different role, as the same logic is not applied to migrants affected by these two infections. I will, therefore, insist on the phase of socio-legal support that professionals provide for migrants with HIV/AIDS or hepatitis $b$.

3.3.1 How are HIV and hepatitis b involved in the "true refugee" recognition?. Before undertaking any administrative procedure for the asylum application, the migrant is advised to meet a social worker to prepare the file he will submit to the territorial commission, which 
rules on his situation. The preparation of the file requires an understanding of the laws and of the functioning of the reception system, so the support of a social work is precious for the migrants in their steps. Given the large number of newly arrived migrants seeking asylum who refer to Samifo, professionals need interviews to select those who will be supported in their administrative process to apply for a residence permit. The application to stay for medical reasons is forwarded at the same time as the application for asylum, then the territorial commission for the recognition of international protection (under the supervision of the Ministry of the Interior) has the competence to rule on the matter and decide, which one of these two residence permits should be issued. In Italy, there are 20 "territorial commissions" formed by four members, namely, two representatives of the Ministries of the Interior, a representative of the local authorities and a representative of the High Commissioner for Refugees. It is not up to the professionals of the association to favour one request over another, this choice formally falling upon the commission's members, as this interview extract shows:

There is no link between AIDS, hepatitis B or other pathologies and the asylum application. The [medical] certificate can play a role when the asylum application is not credible, if the person's story is not accurate. If the application is rejected but the migrant has a serious illness, he can get a residence permit for humanitarian reasons. We often send a medical certificate attesting that a migrant is affected by AIDS to the Commission. Of course we have to convince the patients, because they do not always agree, afterwards it is the Commission that decides, and frankly, I don't think that the two questions (the pathology and the asylum application) are linked (Vincent, operator of Samifo).

The "triage" (Nguyen, 2009) between the "true" and the "false" refugee applies even before the migrant reports to the commission. For professionals who prepare administrative applications with migrants, some illnesses may be considered as a part of the life history of the asylum seeker. This is especially true in the case of sexually transmitted diseases, including HIV, which, according to one of the professionals, might renew the relationship between executioner and victim, extending the experience of torture in the new life. It's as if the suffering continued in the blood.

The attention paid to the medical certificate varies according to the type of pathology from which the migrant is suffering. In the case of HIV/AIDS, the document is sent to the territorial commission in a closed envelope to respect the patient's personal information. In some cases, as shown by research conducted in France (Musso, 2012; Ticktin, 2011), asylum seekers refuse to use their illness to obtain a residence permit. Although HIV can be used as an evidence that the life-story told by the migrant is true, the migrant does not always agree to inform the territorial commission of his HIV/AIDS:

"I discovered my illness here in Italy. I found out that I was infected here, when I worked in the agricultural fields in Calabria. I didn't have this disease before. For me it was a shock, I was afraid to die. I do not want the people of my country to know about it, and that people in the centre where I sleep must not know it either. For the interview with the Commission, Andrea [the operator] gave me a certificate. I did not accept. There is always a mediator there and he often comes from the same country as the asylum seeker" (Segne, 40, Cameroonian asylum seeker living in Italy for a year).

Segne's asylum application was rejected for lack of consistency and details in his history. To go to court, the lawyer convinced him to discuss about his HIV/AIDS with the members of the commission considering the infection as part of his experiences of torture. Because of this crucial new element, Segne obtained refugee status. This because HIV/AIDS has been considered as a proof of the validity of his asylum application.

When it comes to migrants living with the HBV, they must request a medical certificate themselves to a doctor, then ask a social worker of the centre to be accompanied in their administrative procedures. However, as this infection among migrant populations has not 
been the subject of any specific public policy, many migrants do not know this procedure, as shown by the case of Samou, a Malian asylum seeker who had been in Italy for six months. I met him at the hospital. Seeing that he was being assisted by Samifo and would have an interview with the territorial commission the following week, I asked him if he had met anyone of the Samifo. He told me he had only been there once, as he arrived in Rome and did not have a reference social worker. I then proposed him to come to the Samifo the next day to inform him thoroughly about the services provided by this association and to discuss his hearing before the commission. When he came, me and a social worker from the centre explained to him that using a medical certificate attesting his infection with HBV would give him more chances to obtain a residence permit. Then, the social worker advised him to go to an infectious disease specialist to obtain a medical certificate confirming his treatment against chronic hepatitis b. Unlike migrants with HIV/AIDS, in the case of HBV, it is not the Samifo' professionals that send the certificate directly (the envelope) to the commission: it is the applicant himself who must present it. This shows that the commission, as well as health and social professionals, has less regard for the hepatitis b asylumseekers than it does for the HIV asylum seekers.

In the case of Samou, the social worker did not consider that his story was quite legitimate to ask for asylum: by "advising" him to use the medical certificate to apply for a residence permit for medical reasons (humanitarian permit), he shifted Samou from the category of asylum seeker to that of diseased migrant. During his meeting with the Commission, Samou told his story and presented the medical certificate attesting his infection with HBV. Sometime later, he was granted a humanitarian permit for medical reasons, which is valid for one year and can only be renewed if the person must continue the therapeutic treatment. The refugee status would have allowed him to have a residence permit for a period of five years.

In the practices of the legal support, the difference between HIV and hepatitis b lies in the fact that hepatitis $b$ leads more often than AIDS a shift from the status of asylum seeker to the status of diseased migrant. Actually, migrants with HBV and hepatitis b tend to associate their infection with HIV/AIDS (Pourette, 2012, 2013). The reason is that some of them do not know hepatitis b before they discover to be infected and because this virus is sexually transmitted, as is HIV/AIDS (Pourette, 2012, 2013). As a result, hepatitis b is associated with HIV and perceived as a shameful and serious illness causing a form of social rejection (Pourette, 2012, 2013). Before his meeting with the Commission, Samou did not want to talk about his illness:

I came here to ask for asylum. I do not understand why I have to talk about my health. In addition, I feel good and I do not understand the usefulness of the medical treatment.

Social representations of sexually transmitted diseases are variable, but the representations that health and social professionals have, are built in relation to the current situation of the migrant and to his past history. In that way, the medical certificate becomes a kind of "proof of truthfulness" of the migrant who, considered as a victim of violence, often sexual violence, must be protected as an asylum seeker and helped to obtain the refugee status. The link between sexuality and HIV seropositivity is not surprising considering, the history of public policies to combat this epidemic:

[...] At symbolic but also at epidemiological level, the disease has not been listed among viral diseases, as in the case of hepatitis B, but among sexually transmitted diseases, such as syphilis.

3.3.2 The shift from the status to asylum seeker to the status of diseased migrant. For health and social professionals, the origin of hepatitis $b$ is often attributed to the transmission of mother-to-child and the link between this disease and sexual violence or torture experiences is not perceived as obvious as in the case of AIDS. On the contrary, for the migrant hepatitis $b$ is primarily a sexually transmitted disease. In the case of Amira, coming 
from Senegal, the virus is part of a history of sexual violence and of which it becomes the detector.

For her, it is the violence inflicted by her husband that caused her infection. She decided to leave her country and seek asylum in Italy because she claimed to be a victim of unwanted sexual intercourse in a forced marriage. She discovered her HBV infection during a consultation at the SAMIFO, but said to have never heard of it before. When confronted with a health professional who told her that hepatitis $b$ is a liver disease, she replied that it was her husband who contaminated her because he was "always sick". Although at first medical and social operators did not doubt her history, Amira had some problems with other people housed in the centre where she was staying. These events led them to express reservations about the veracity of her words. A few months after assisting Amira, some professionals felt that her story was incoherent:

"It's always the same story of the violent husband, there is no precision, she does not go into details. She says she does not speak Italian, but I think she understands the language. In

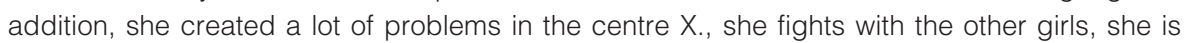
violent" (Elisa, operator at SAMIFO).

For the operators, the disease is not the main argument of their conversation but it is rather part of a set of elements (coherence of the life story, behaviour within the accommodation centres, knowledge of language, etc.) largely taken into account by medical professionals and social workers to assess the validity of an asylum application, and thus, to differentiate the "true" from the "false" refugee. In the case of Amira, two doubts weigh on her and fall within two logics, namely, the first one related to the dichotomy between "true" and "false" refugee, which weighs on her life story and her daily attitudes (Kobelinsky, 2007), and the other one inherent to the biomedical logic, which weighs on the uncertain origin of hepatitis $\mathrm{B}$ (mother-to-child transmission rather than non-consensual sexual intercourse in the context of forced marriage).

As Francesco Vacchiano (2011) shows in his study on the selection of migrants to be housed in Italian centres, migrants who "deserve" to be received and cared for are those who accept their precarious situation and remain in the role of the individual in need of help, with gratitude and modesty: [...] the true refugee must show all the characteristics that identify him as a person who is imagined as living in a state of necessity, in other worlds, the real victim (Francesco Vacchiano, 2011, p. 185).

In other words, for having access to rights, migrants must behave as expected by professionals (Butler, 1997). This is even more true for women, considered as doubly vulnerable, on the one hand because they are seeking asylum and on the other, because they are female victims of a different and violent social order (Pinelli, 2011; Spivak, 2009; Sorgoni, 2011; Ticktin, 2011). In her analysis of the reception of migrant women in southern Italian regions, Barbara Pinelli (2011) shows how the representations that the operators have of these women are based on stereotypes about gender and ethnicity: deprived of their capacity of action because of their status of victims, women must be helped but also trained to become autonomous, "modern women" (Barbara Pinelli, 2011, p. 86). However, if the capacity of a woman who asks for asylum does not stick with this imaginary, she can quickly be perceived as being a "false" refugee (Sorgoni, 2011). In the case of Amira, her illness and her history are not enough to consider her as a victim, her actions not falling within the framework of the possible actions of the "woman who asks for asylum", therefore, slipped from the status of asylum seeker to that of a diseased migrant. Moreover, the fact that she associates its infection with HBV to a violence that has been experienced generated in medico professionals and social workers a stronger feeling of suspicion. Today, Amira no longer needs to be treated for hepatitis b, so her one-year medical residence permit (humanitarian permit) was not renewed. Being in an irregular situation, she decided to file an appeal for her asylum application to be investigated. 


\section{Conclusion}

The fact is that they are so many migrants, and we cannot look after everyone. The reception system is not able to meet the needs of all migrants, the governments don't consider this problem as a priority. The SAMIFO, meanwhile, only works with migrants forced to leave their country, not with others (Ada, doctor at Samifo).

This reflection sheds light on the process of constructing legal categories for newly arrived migrants living with HIV or hepatitis $b$ and seeking for a humanitarian permit or for asylum.

In doing so, the article adds to the debate about the role of the civil society actors engaged in service provision in migration control policies. In this regard, some scholars have stressed out that these actors, filling the gap between the official legal framework and the real needs of irregular migrants, become functional to the system (Castañeda, 2007; d'Halluin, 2012). Other scholars have highlighted the complexity of their actions showing that "they also act in the political arena to assert the rights of migrants" (Ambrosini, 2015, p. 130).

Focusing on the daily practices of socio-legal support to newly arrived migrants living with HIV/AIDS or hepatitis $b$, this article has shown that third sector actors not only find themselves obliged to define and select whom they can help and whom not (Ambrosini and Van der Leun, 2015; Castañeda, 2008; Santilli, 2017), they also participate in the creation of legal categories assigned to migrants. More specifically, the data show how the shift from the category of a newly arrived migrant to that of asylum seeker or to that of diseased migrant is constructed and varies according to the interactions between health and social professionals and migrant patients. This shift happens even before the intervention of the competent public institutions, which decide on the issue of a residence permit.

Based on the extracts of interviews and on case studies, this work highlights the process of incorporation and internalization of the two logics mentioned above, namely, the logic of selection to control migratory flows and that of universalism. The tension between the universal right to health care and the tightening of migration policies is reflected in the implementation of a differentiated treatment of migrants according to their social status, their pathology and their behaviours. Biomedical knowledge becomes, in this case, one of the tools for classifying and prioritizing the vulnerability of migrants. In view of the health status of migrants affected by HIV/AIDS, medical and social staff feels obliged to help them and assist them in their administrative and legal journey. For an asylum seeker, being infected with HIV/AIDS can play the role of scientific proof of the violence suffered, and thus, create a compassionate feeling, helping them to be granted the refugee status. On the contrary, the uncertain origin of the infection with HBV, the less visible effects on the body, the idea that the transmission of this virus is not linked to the violence suffered, cause less involvement among professionals of Samifo, who tend to let migrants and doctors manage this issue.

Many studies have already shown how, in countries where the right to health care for all migrants is granted such as France and - as shown in this article - Italy, the illness appears to produce the right to citizenship (Fassin, 2001; Musso, 2012; Ticktin, 2011). In this article, I compared two infections and showed how their different political histories and representations lead not only to different social treatments but also to two local forms of "biocitizenship" linked to the policies of suspicion (Petryna, 2002; Nguyen, 2009). In fact, we can see the refugee, who is granted this status because of the disease and who has the right to a stable legal status in Italy, and the diseased migrant, with a residence permit for health care, who becomes irregular once the treatment is completed. The intersection between the evolution of the political fight against these two infections and the national migration policies has an impact on this process rather than their biomedical characteristics. This highlights that not all kinds of illness produce the right or the same right to citizenship and that it also depends on specific circumstances and context. 
As Giovanni Pizza points out, the rhetoric of the absence of the state, in marginal places, is a linguistic procedure that helps to build a specific form of its presence (Pizza, 2011, p. 24). By becoming part of the "social economy" area set up in the 1990s to provide for the deficiencies of a welfare state in crisis (Fassin, 2013), the Samifo becomes a place where public policies are implemented and where the weight of legal categories materializes. Individual interactions seem to play a key role in the manifestation of this form of exercise of the state power in the third sector area.

\section{References}

Alder, P.A. and Alder, P. (2000), "Observational techniques", in Denzin, N.K. and Lincoln, Y.S. (Eds), Handbook of Qualitative Research, Sage, Thousand Oaks, CA, pp. 377-392.

Ambrosini, M. (2015), "NGOs and health services for irregular immigrants in Italy: when the protection of human rights challenges the laws", Journal of Immigrant \& Refugee Studies, Vol. 13 No. 2, pp. 116-134.

Ambrosini, M. and Van der Leun, J. (2015), "Introduction to the special issue: implementing human rights: civil society and migration policies", Journal of Immigrant \& Refugee Studies, Vol. 13 No. 2, pp. 103-115.

Borzaga, C. and Fazzi, L. (2011), "Processes of institutionalisation and differentiation in the Italian third sector", Voluntas: International Journal of Voluntary and Nonprofit Organizations, Vol. 22 No. 3, pp. 409-427.

Borzaga, C. and Fazzi, L. (2014), "Civil society, third sector, and healthcare: the case of social cooperatives in Italy", Social Science \& Medicine, Vol. 123, pp. 234-241.

Bosi, L. and Zamponi, L. (2015), "Direct social actions and economic crises: the relationship between forms of action and socio-economic context in Italy", Partecipazione e Conflitto, Vol. 8 No. 2, pp. 367-391, doi: 10.1285/i20356609v8i2p367.

Butler, J. (1997), Excitable Speech: A Politics of the Performative, Routledge, New York.

Caponio, T. and Cappiali, T.M. (2018), "Italian migration policies in times of crisis: the policy gap reconsidered", South European Society and Politics, Vol. 23 No. 1.

Castañeda, H. (2007), "Paradoxes of providing aid: NGOs, medicine, and undocumented migration in Berlin, Germany”, Doctoral dissertation, University of Arizona Graduate College, Tucson, AZ.

Castañeda, H. (2008), "Illegal migration, gender and health care: perspectives from Germany and the United States”, in Schrover, M., Van der Leun, J., Lucassen, L. and Quispel, C. (Eds), Gender and IIlegal Migration in Global and Historical per-Spective, Amsterdam University Press, Amsterdam, pp. 171-188.

Castaneda, H. (2009), "Illegality as risk factor. A survey of unauthorized migrant patients in a Berlin clinic", Soc. Sci. Med, Vol. 68 No. 1, pp. 1552-1560.

Dal Lago, A. (2004), Non persone. L'esclusione dei migranti in una società globale, Feltrinelli, Nuova Edizione, Milano.

De Genova, N. (2002), "Migrant 'illegality' and deportability in everyday life", Annual Review of Anthropology, Vol. 31 No. 1, pp. 419-447.

Delle Donne, M. (1995), "La strada dell'Oblio", Richiedenti D'asilo e Rifugiati in Italia, Sensibili alla Foglie, Roma.

Desgrées Du Loû, A., Pannetier, J., Ravalihasy, A., Gosselin, A., Supervie, V., Panjo, H., Bajos, N., Lert, F., Lydié, N. and Dray-Spira, R. (2015), "Migrants subsahariens suivis pour le VIH en France: combien ont été infectés après la migration? Estimation dans l'Étude parcours (ANRS)", Bull Epidémiol Hebd, Vols 40/41, pp. 752-778, groupe ANRS-Parcours.

d'Halluin-Mabillon, E. (2005), "Vaincre la suspicion, entrer dans une intimitédouloureuse : une intenable extériorité", in Bouillon, F., Fresia, M. and Tallio, V. (Eds), Terrain sensibles. Expériences actuelles de l'anthropologie, CEA-EHESS, Paris, pp. 55-74.

d'Halluin-Mabillon, E. (2012), Les épreuves de l'asile, éditions EHESS, Paris.

Fassin, D. (2001), "Charité bien ordonnée. Principes de justice et pratiques de jugement dans l'attribution des aides d'urgence", Revue Française de Sociologie, Vol. 42 No. 3, pp. 437-475. 
Fassin, D. (2013), “Introduction. Au coeur de l'Etat”, in Fassin, D. (Ed.), Juger, Réprimer, Accompagner. Essai Sur la Morale de LÉtat, Le Seuil, Paris.

Giarelli, G., Annandale, E.C. and Ruzza, C. (Eds) (2014), "The role of civil society in healthcare systems reforms", Social Science and Medicine, Vol. 123, pp. 1-294.

Holmes, S. and Castañeda, H. (2016), "Representing the European refugee crisis in Germany and beyond: deservingness and difference, life and death", American Ethnologist, Vol. 43 No. 1, pp. $12-24$.

Istituto superiore di sanita (2015), "Aggiornamento delle nuove diagnosi di infezione da HIV e dei casi di Aids in Italia al 31 dicembre 2015", American Ethnologist, Vol. 28 No. 9, available at: www.iss.it/binary/ ccoa/cont/HIV_AIDS_DIC_2015.pdf

Kobelinsky, C. (2007), "Le jugement quotidien des demandeurs d'asile", Recueil Alexandries, Collections Esquisses, available at: http://www.reseau-terra.eu/article559.html

Lipsky, M. and Smith, S.R. (1993), "Nonprofit for hire", The Welfare State in the Age of Contracting, Harvard University Press, Cambridge.

Morroi, M. (2012), "Le traitement des demandeurs d'asile en Italie", Hommes et Migrations, Vol. 1300, pp. 72-82.

Musso, S. (2012), "Être régularisé au titre de la maladie en France”, Corps, Vol. 10 No. 1, pp. 153-163.

Musso, S., Sakoyan, J. and Mulot, S. (Eds) (2012), "Migrations et circulations thérapeutiques: odysséeset espaces", Anthropologie \& Santé [En ligne], 5 | 2012, mis en ligne le 26 novembre 2012, consulté le 07 juillet 2017, doi: 10.4000/anthropologiesante.1040, available at: http://anthropologiesante.revues.org/ 1040

Nguyen, V.K. (2009), "Government-by-exception: enrolment and experimentality in mass HIV treatment programmes in Africa", Social Theory \& Health, Vol. 7 No. 3, pp. 196-217.

Petryna, A. (2002), Life Exposed: Biological Citizens after Chernobyl, Princeton University, Princeton.

Pinelli, B. (2011), "Attraversando il mediterraneo. II sistema campo in Italia: violenza e soggettività nelle esperienze delle donne", Lares, Vol. LXXVII No. 1, pp. 159-180.

Pizza, G. (2011), "Introduzione. Pizza, G. \& Ravenda, A. Presenze internazionali. Prospettive etnografiche sulla dimensione fisico-politica delle migrazioni in Italia", Rivista Della Società Italiana di Antropologia Medica, pp. 33-34.

Pugliese, E. (2002), L'Italia Tra Migrazioni Internazionali e Migrazioni Interne, II Mulino, Bologna.

Pourette, D. (2012), "Améliorer la prise en charge des patients migrants porteurs d'une hépatite", La Santé de l'Homme (revue de l'INPES) (n422), pp. 47-49.

Pourette, D. (2013), "Prise en charge du VIH et de l'hépatite B chronique chez les migrants subsahariens en France: le rôle-clé de la relation médecin-patient", Santé Publique Vol. 25 No. 5, pp. 561-570.

Ravenda, A.F. (2011), Al di Fuori Dalla Legge. Migrazione, Biopolitica e Stato D'eccezione in Italia, Ombre Corte, Verona.

Rice, B.D., Elford, J., Yin, Z. and Delpech, V.C. (2012), "2A new method to assign country of HIV infection among heterosexuals born abroad and diagnosed with HIV", AIDS, Vol. 26 No. 15, pp. 1961-1966.

Rosenthal, A. (2007), "Battling for survival, battling for moral clarity: 'illegality' and illness in the everyday struggles of undocumented HIV+ women migrant workers in Tel Aviv", OIM International Migration, Vol. 45 No. 3, pp. 134-156.

Sakoyan, J. (2008), "L'éthique multi-située et le chercheur comme acteur pluriel. Dilemmes relationnels d'une ethnographie des migrations sanitaires", Numéro 17, available at: ethnographiques.org

Santilli, C. (2017), "Accès aux soins et Politiques migratoires en Europe", Le parcours de vie des migrants subsahariens vivant avec le VIH et l'hèpatite b. Un regard croisèentre la France et l'Italie, PhD diss. AixMarseille University.

Seiva (2015), "Workshop SEIVA", available at: www.iss.it/binary/seie2/cont/Baglio_workshop_SEIEVA. pdf

Sorgoni, B. (2011), "Chiedere asilo in Europa. Confini margini e soggettività", Lares, Vol. LXXVII No. 1, pp. 1-10. 
Spivak, G.C. (1988), "Can the Subaltern speak?", in Nelson, C. and Grossberg, L. (Eds), Marxism and the Interpretation of Culture, University of Illinois, Chicago, pp. 271-313.

Strauss, A. and Corbin, J. (1994), "Grounded theory methodology: an overview", in Denzin, N.K. and Lincoln, Y.S. (Eds), Handbook of Qualitative Research, Sage Publications, Inc, pp. 273-285.

Ticktin, M. (2011), "Casualties of care: immigration and the politics of humanitarianism in France", University of California Press, Berkeley.

Vacchiano, F. (2011), "Discipline della scarsità e del sospetto: rifugiati e accoglienza nel regime di frontiera", Lares, LXXVII, 1, gennaio-aprile 2011, pp. 181-198.

Vidal, L. (1996), Le silence et le sens : essai d'anthropologie du sida en Afrique, Anthropos, Paris.

WHO (2015), "News releases", available at: www.who.int/mediacentre/news/releases/2015/hepatitis-bguideline/fr/

Willen, S. (2012), "How is health-related 'deservingness' reckoned? Perspectives from unauthorized im/ migrants in Tel Aviv", Soc. Sci. Med, Vol. 74 No. 6, pp. 812-821.

Willen, S. (2015), "Lightning rods in the local moral economy: debating unauthorized migrants' deservingness in Israel", OIM International Migration, Vol. 53 No. 3, pp. 70-86.

Zamponi, L. (2018), "Practices of solidarity: direct social action, politicisation and refugee solidarity activism in Italy", Mondi Migranti, Vol. 3, pp. 97-117.

Zincone, G. (1999), "Illegality, enlightenment and ambiguity: a hot Italian recipe", in Baldwin-Edwards, M. and Arango, J. (Eds), Immigrants and the Informal Economy in Southern Europe, Frank Cass, London, pp. 43-82

Zincone, G. (2011), "The case of Italy", in Zincone, G., Penninx, R. and Borkert, M. (Eds), Migration Policymaking in Europe, IMISCOE Research, Amsterdam University Press, Amsterdam, pp. 247-290.

Zuccaro, O., Tosti, M.E. and Mele, A. (2012), "Epidemiologia dell'epatite B in Italia dopo l'introduzione della vaccinazione universale per HBV", in Appelgren, E.C. and Luzi (Eds), Convegno La salute degli italiani nei dati del Centro Nazionale di Epidemiologia, Sorveglianza e Promozione della Salute (CNESPS). Istituto Superiore di Sanità. Roma, 16-17 giugno 2011. Atti. Roma: Istituto Superiore di Sanità, (Rapporti ISTISAN 12/05), pp. 67-72.

\section{Further reading}

Enel, C. and Pourette, D. (2014), "Représentations et vécu de l'hépatite b des patients subsahariens en Côte d'Ivoire et en France”, S.F.S.P Santé Publique, Vol. 26 No. 6, pp. 869-878.

Fassin, D. (2004), "Social illegitimacy as a foundation of health inequality: how the political treatment of immigrants illuminates a French paradox", in Castro, A. and Singer, M. (Eds), Unhealthy Health Policy: A Critical Medical Examination, Altamira Press, Walnut Creek, CA.

Fassin, D. and d'Halluin, E. (2005), "The truth from the body: medical certificates as ultimate evidence for asylum seekers”, American Anthropologist, Vol. 107 No. 4, pp. 598-608.

SEIEVA - Sistema Epidemiologico Integrato dell'Epatite Virale Acuta (2012), Rapporto Nazionale 2012.

\section{Corresponding author}

Cecilia Santilli can be contacted at: santilli.cecilia@gmail.com

For instructions on how to order reprints of this article, please visit our website: www.emeraldgrouppublishing.com/licensing/reprints.htm

Or contact us for further details: permissions@emeraldinsight.com 